\title{
Chronic Subdural Hematomas: Single or Double Burr Hole-Results of a Randomized Study
}

\section{Kronik Subdural Hematomlar:Tek ve Çift Bur Deliği-Randomize Bir Çalışmanın Sonuçları}

\author{
Khursheed NAYIL ${ }^{1}$, Ramzan ALTAF ${ }^{1}$, Yawar SHOAIB ${ }^{1}$, Abrar WANI ${ }^{1}$, Masood LAHARWAL ${ }^{1}$, Amer ZAHOOR $^{2}$
}

${ }_{1}^{1}$ Sheri-Kashmir Institute of Medical Sciences, Department of Neurosurgery, Kashmir, India

${ }^{2}$ Sheri-Kashmir Institute of Medical Sciences, Department of Anesthesiology, Kashmir, India

Corresponding Author: Khursheed NAYIL / E-mail: nayilkhursh@gmail.com

\begin{abstract}
AIM: To analyze the analysis of recurrence rates of single versus double burr holes in patients with subacute and chronic subdural hematomas. MATERIAL and METHODS: The study was a prospective randomized controlled trial on patients with subacute and chronic subdural hematomas. Collections with membranes or septae were excluded from the study. A written consent was taken from the patient or patient party after explaining the procedure. A total of 254 patients were enrolled in the study over a period of 18-months in the Department of Neurosurgery, Sheri-Kashmir-Institute of Medical Sciences, Srinagar, Kashmir.

RESULTS: Recurrence rates in single and double-burr-hole groups were $6.15 \%$ and $4.83 \%$ respectively, which was not statistically significant. CONCLUSION: Most of the subdural hematomas can be dealt by single burr-hole drainage.

KEYWORDS: Subdural hematoma, Chronic subdural hematoma, Burr-hole drainage, Recurrence

Öz

AMAÇ: Subakut ve kronik subdural hematomlu hastalarda tek ve çift bur deliğiyle nüks oranlarını analiz etmek.

YÖNTEM ve GEREÇLER: Bu çalışma, subakut ve kronik subdural hematomlu hastalarda prospektif bir randomize kontrollü çalışmaydı. Membranlar veya septumlar bulunan hastalar çalışmaya alınmadı. İşlem açıklandıktan sonra hastadan veya hasta yakınından yazılı onay alındı. Çalışmaya Kashmir'de Srinagar'daki, Sheri-Kashmir-Tıbbi Bilimler Enstitüsü Nöroşirürji Bölümünden 18 aylık bir süre boyunca 254 hasta kaydedildi.
\end{abstract}

BULGULAR: Tek ve çift bur deliği gruplarında nüks oranları sırasıyla \%6,15 ve 4,83 bulundu ve bunlar istatistiksel olarak anlamlı değildi.

SONUÇ: Subdural hematomların çoğunda tek bur deliği drenajı yeterlidir.

ANAHTAR SÖZCÜKLER: Subdural hematom, Kronik subdural hematom, Bur deliği drenajı, Nüks

\section{INTRODUCTION}

Subdural hematomas are a well-known entity in neurosurgical practice. The etiology of subdural hematomas is commonly attributed to head injury in about $50 \%$ of the patients $(10,11)$. In rest of the patients definite cause is not known. Subdural hematomas are classified as acute, sub-acute and chronic depending on the time of diagnosis from the day of injury as acute within 3 days of injury, subacute from 3 days to 3 weeks of injury and chronic more than 3 weeks after injury $(9,19)$. Subdural hematomas can also be classified on the basis of texture of the hematoma on plain CT scan with hyperdense hematoma as acute subdural, isodense as subacute and chronic as hypodense (14). Twist drill craniostomy, burr-hole drainage or craniotomy are the various methods to deal with subdural hematomas $(13,17)$. The recurrence rates vary from $8-26 \%(6,20)$. Various factors have been noted to have a bearing on recurrence rates that include multilocularity of the collection and presence of coagulopathy (7). However the issue of effect of number of burr holes on the recurrence of subdural hematomas has not been well settled. This study was undertaken to address this issue.

\section{MATERIAL and METHODS}

\section{Design of the Study}

We conducted a randomized controlled study over a period of 18-months, from July 2010 to December 2011 in the Department of Neurosurgery at Sher-i-Kashmir Institute of Medical Sciences, Kashmir, India. All patients with a CT diagnosis of subacute and chronic subdural hematomas were enrolled in the study, however patients with multilocular collections in the chronic subdural hematoma group were excluded. 


\section{Patient Population}

We enrolled a total of 258 patients with this diagnosis who were allocated according to the random table to the 2 groups as one receiving single burr-hole and the other, 2 burr-holes. At the end of the study i.e., 18 months period plus the 6 -months period after the last patient was operated upon, the results of the study were analyzed. We lost 2 patients to follow-up and 2 patients died while in hospital after the evacuation of the subdural hematoma, these 4 patients were excluded from the study and hence at the end of the study we were left with 254 patients. The analysis was done on 254 patients. Demographic characteristics, operative modalities, and recurrence rate was noted. Patients were followed-up in Neurosurgical outpatient-department. CT scan was done in follow-up patients only if patients would become symptomatic for recurrence. Recurrence on follow-up on the opposite side of previous surgery was supposed to be counted as a new patient; however we did not have such a patient. Single burr-hole was put on posterior parietal region and double burr hole was put on posterior parietal and posterior frontal regions under local anesthesia and intravenous sedation. The subdural space was irrigated thoroughly with normal saline by means of a soft silastic catheter in all the patients. The same catheter was left in the subdural space and connected to a collection bag. The drain was put through parietal burr hole and taken out through a separate stab incision about $5 \mathrm{~cm}$ away from the parietal burr hole site. Patients were nursed in flat position for 48 hours in the postoperative period. The subdural drain was kept for $48 \mathrm{hrs}$ for all the patients.

\section{Statistical Analysis}

Statistical analysis was done by SPSS version 19. The Fisher exact test and Students t-test were used for categorical and continuous variables respectively. A p value of 0.05 or less was considered as significant.

\section{RESULTS}

There were 130 patients who received single-burr hole and 124 patients who received double-burr hole for drainage. The parameters of both the groups are given in Table I, and both the groups were comparable. The overall recurrence rate was $4.72 \%$, it was $6.15 \%$ in the single-burr hole group and $4.83 \%$ in the double-burr hole group, statistically insignificant $(p=$ 0.785)

\section{DISCUSSION}

The treatment of chronic subdural hematomas has drastically evolved over time $(1,3,8,12,18,21)$. Among these procedures burr-hole drainage is the commonest procedure undertaken $(2,7)$. Literature is replete with retrospective analysis of patient with chronic subdural hematoma management. Though there are some randomized controlled trials in chronic subdural hematomas which discuss the issue of burr hole irrigation with or without drainage $(5,15)$, twist drill drainage for 48 vs, 96 hrs (4); till date, to our knowledge, there is no randomized trial that has compared the recurrence rates of single versus double burr-hole therapy in patients with subacute and chronic subdural hematomas. We put a subdural drain in all the patients in view of the low recurrence rates as proved by a previous randomized trial (15). The overall recurrence rate in our present series was low (5.5\%), as compared to our previous observational study (6.48\%) (7). This low recurrence rate is possibly because of the strict use of subdural drains in all the patients. In our previous study (7) we noticed that multilocular collections have high risk of recurrence. The explanation given in the literature for high incidence of postoperative recurrence in such subdural collections is the hyperfibrinolytic activity and tendency to re-bleed from the membrane (16). Since we excluded multilocular collections in the present study, this could also explain why the recurrence in our present series is even less than in our past series in which we have included multilocular collections. Kansal (6) in his observational study of 267 cases in which he has excluded patients with bilateral collections, coagulopathy, and significant brain atrophy also found no statistically significant difference between recurrence rates after single or double burr hole drainage. However our study is a randomized trial and we have included patients with bilateral subdural collections and coagulopathy. We observed that these factors have no bearing on the recurrence of the hematoma whether these receive a single or a double-burr hole drainage (Table I).

\section{CONCLUSIONS}

Based on our prospective randomized trial we conclude that a single burr-hole is as efficacious as a double-burr-hole in terms of recurrence in the evacuation of subacute and chronic subdural hematomas. We hence stress the use of single-burr hole for subdural collections (except multilocular collections) as it is less invasive.

Table I: Factors Have No Bearing on the Recurrence of the Hematoma Whether These Receive a Single or a Double-Burr Hole Drainage

\begin{tabular}{|l|c|c|c|}
\hline Parameter & Single-burr hole $(\mathbf{n = 1 3 0 )}$ & Double-burr hole $(\mathbf{n = 1 2 4 )}$ & P value \\
\hline Age (mean) & $61.01 \mathrm{yrs}$ & 61.17 yrs & 0.879 (NS) \\
\hline Gender & $\mathrm{M}=74, \mathrm{~F}=56$ & $\mathrm{M}=68, \mathrm{~F}=56$ & 0.273 (NS) \\
\hline Coagulopathy & 20 & 14 & 0.794 (NS) \\
\hline Bilaterality & 21 & 13 & 0.201 (NS) \\
\hline Recurrence & $8(6.15 \%)$ & $6(4.83 \%)$ & 0.785 (NS)
\end{tabular}

NS= not significant. 


\section{REFERENCES}

1. Drapkin AJ: Endoscopy for chronic SDH. Surg Neurol 48:427,1997

2. Gazzeri R, Galaraza M, Neroni M, Canova A, Refice GM, Esposito $S$ : Continuous subgaleal suction drainage for the treatment of chronic subdural haematoma. Acta Neurochir (Wien) 149:487-493, 2007

3. Horn EM, Feiz-Erfan, Bristol RE, Spetzler RF, Harrington TR: Bedside twist drill craniostomy for chronic subdural hematoma: A comparative study. Surg Neurol 65:150-154, 2006

4. Ibrahim I, Maarrawi J, Jouanneau E, Guenot M, Mertens P, Sindou M: Evacuation of chronic subdural hematoma with the twist-drill technique. Results of a randomized prospective study comparing 48-h and 96-h drainage duration: Neurochirurgie 56(1): 23-27,2010

5. Javadi A, Amirjamshidi A, Aran S, Hosseini SH: A randomized controlled trial comparing the outcome of burr-hole irrigation with and without drainage in the treatment of chronic subdural hematoma: a preliminary report. World Neurosurg 75(5-6):731-736,2011

6. Kansal R, Nadkarni T, Goel A: Single versus double burr hole drainage of chronic subdural hematomas. A study of 267 cases. J Clin Neurosci 17(4):428-429, 2010

7. Khursheed N, Ramzan A, Sajad A, Zahoor S, Wani A, Nizami F, Laharwal M, Kirmani, Bhat A: Subdural hematomas: An analysis of 1181 Kashmiri patients and review of literature. World Neurosurg 77(1):103-110, 2012

8. Lee JY, Ebel H, Ernestus RI, Klug N: Various surgical treatments of chronic subdural hematoma and outcome in 172 patients: Is membranectomy necessary? Surg Neurol 61:523-528, 2004

9. Macfarlane MR, Weerakkody Y, Kathiravel Y: Chronic subdural haematomas are common on left than on the right. J Clin Neurosci 16:642-644, 2009

10. Markwalder TM: Chronic subdural haematomas: A review. J Neurosurg 54(5):637-645, 1981

11. Matsumoto K, Akagi K, Abekura M, Ryujin H, Ohkawa M, Iwasa N, Akiyama C: Recurrence factor for chronic subdural haematomas after burr-hole craniostomy and closed system drainage. Neurol Res 21(3):277-280,1999
12. Mohamed EE: Chronic subdural haematoma treated by craniotomy durectomy outer membranectomy and subgaleal suction drainage. Personal experience in 39 patients. $\mathrm{Br} \mathrm{J}$ Neurosurg 17:244-247, 2003

13. Muzii VF, Bistazzoni S, Zalaffi A, Carangelo B, Mariottini A, Palma L: Chronic subdural hematoma: Comparison of two surgical techniques. Preliminary results of a prospective randomized study. J Neurosurg Sci 49:41-47, 2005

14. Osborn AG: Diagnostic Neuroradiology. St. Louis, MO: Mosby, 1994:205-211

15. Santarius T, Kirkpatrick PJ, Ganesan D, Chia HL, Jalloh I, Smielewski P, Richards HK, Marcus H, Parker RA, Price SJ, Kirollos RW, Pickard JD, Hutchinson PJ: Use of drains versus no drains after burr-hole evacuation of chronic subdural haematoma: A randomised controlled trial. Lancet 374(9695), 1067-1073, 2009

16. Stanisic M, Lundh-Johansen M, Mahesparan R: Treatment of chronic subdural hematoma by burr-hole craniostomy in adults: Influence of some factors on post-operative recurrence. Acta Neurochir (Wien) 147:1249-1256, 2005

17. Weigel R, Schmiedek P, Krauss JK: Outcome of contemporary surgery for chronic subdural haematoma: Evidence based review. J Neurol Neurosurg Psychiatry 74:937-943, 2003

18. Weisse A, Berney J: Chronic subdural haematomas: Results of a closed drainage method in adults. Acta Neurochir (Wien) 127:37-40, 1994

19. Wilkins RH, Rengachary SS: Neurosurgery. 2nd ed. Volume 3. New York: McGraw-Hill Health Professions Division, 1996:2799-2801

20. Zakaraia AM, Adnan JS, Haspani MS, Naing NN, Abdullah JM: Outcome of 2 different types of operative techniques practiced for chronic subdural hematoma in Malaysia: An analysis. Surg Neurol 69(6):608-615, 2008

21. Zumofen D, Regli L, Levivier M, Krayenbühl N: chronic subdural hematomas treated by burr hole trepanation and a subperiostal drainage system. Neurosurgery 64: 1116-1122, 2009 